Miami Nature Biotechnology Short Reports

TheScientificWorld (2001) 1 (S3), 92SR

ISSN 1532-2246; DOI 10.1100/tsw.2001.205

\title{
THE ROLE OF XCHK1 IN THE INHIBITION OF APOPTOSIS
}

\author{
Ayesha D. Carter and Jill C. Sible \\ Department of Biology, Virginia Tech, Blacksburg, VA 24061-0406 USA \\ aycarter@vt.edu
}

INTRODUCTION. Embryonic cell cycles of Xenopus laevis provide rare examples of nonpathological cell divisions that lack cell cycle checkpoints $(1,2)$. Following fertilization, the Xenopus egg begins twelve rapid oscillations between DNA replication and mitosis without growth, gap phases, or checkpoints. Completion of the twelfth cleavage marks the midblastula transition (MBT) when transcription begins, and the cell cycle remodels, lengthening as it acquires gap phases, checkpoints and a program of apoptosis (3). We are investigating the relationship between Xenopus Chk1 (XChk1) signaling and apoptosis in the developing embryo.

METHOD. One-cell embryos were injected with mRNA encoding catalytically inactive XChk1 to inhibit endogenous XChk1 or luciferase as a control. To induce a DNA replication checkpoint, embryos were treated after the MBT with $100 \mu \mathrm{g} / \mathrm{ml}$ aphidicolin. DNA fragmentation associated with apoptosis was determined by whole mount TUNEL assays and by the resolution of DNA ladders from extracts of genomic DNA (1).

RESULTS. When treated with aphidicolin at Stage 9 of development (post-MBT), the embryos expressing inactive, dominant negative XChk1 exhibited a dramatic apoptotic-like cell death during gastrulation (Fig. 1). Subsequent resolution of genomic DNA from these embryos showed the DNA ladders characteristic of apoptotic death. Further analysis by TUNEL assay labeling the fragmented DNA confirmed that this death was due to apoptosis (Fig. 2).

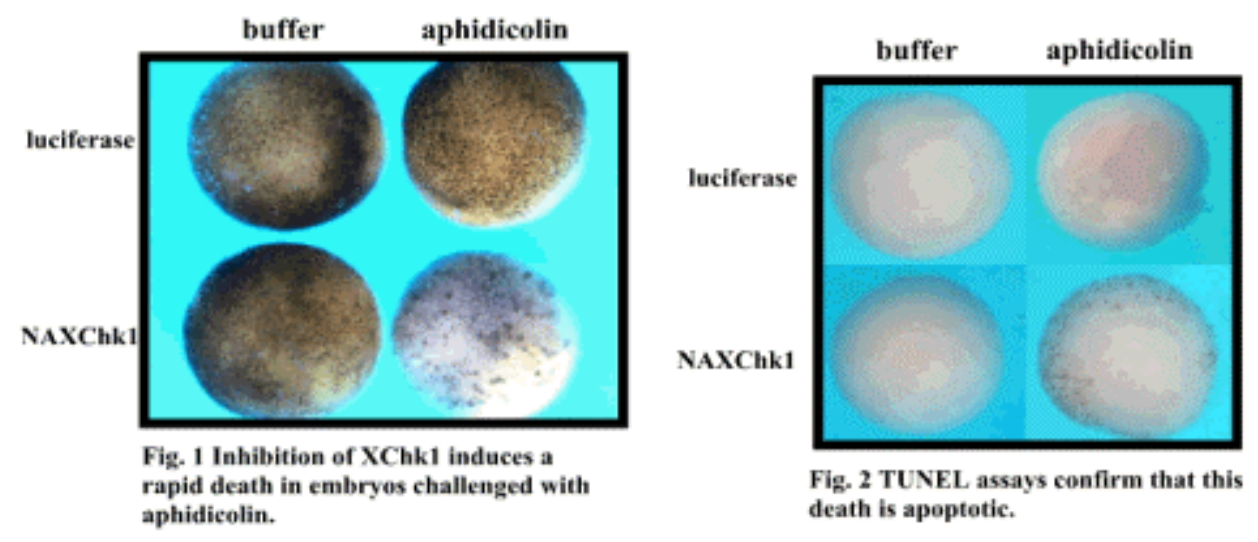

DISCUSSION. These experiments support the hypothesis that XChk1 normally blocks apoptosis after the MBT. We have recently determined that XChk1 is an inhibitor of Cdc2 and Cdk2 (4) and it is possible that this is the mechanism by which XCk1 inhibits apoptosis. 
Therefore, XChk1 may function as a molecular switch to determine whether a cell will enter a cell cycle checkpoint (XChk1 on, Cdk2 off) or a program of apoptosis (XChk1 off, Cdk2 on).

ACKNOWLEDGEMENTS. This research was supported by grants from the National Institutes of Health (GM59688-01A1) to J. Sible, and by the State Dean Minority Fellowship to A. Carter.

\section{REFERENCES.}

1. $\quad$ Sible, J., Anderson, J., Lewellyn, A., and Maller, J. (1997) Dev. Biol. 189, 335

2. Anderson, J., Lewellyn, A., and Maller, J. (1997) Mol. Biol. Cell 8, 1195

3. $\quad$ Stack, J. and Newport, J. (1997) Development 124, 3185-3196

4. $\quad$ Kappas, N., Savage, P., Chen, K., Walls, A., and Sible, J. (2000) Mol. Biol. Cell 11, 31013108 

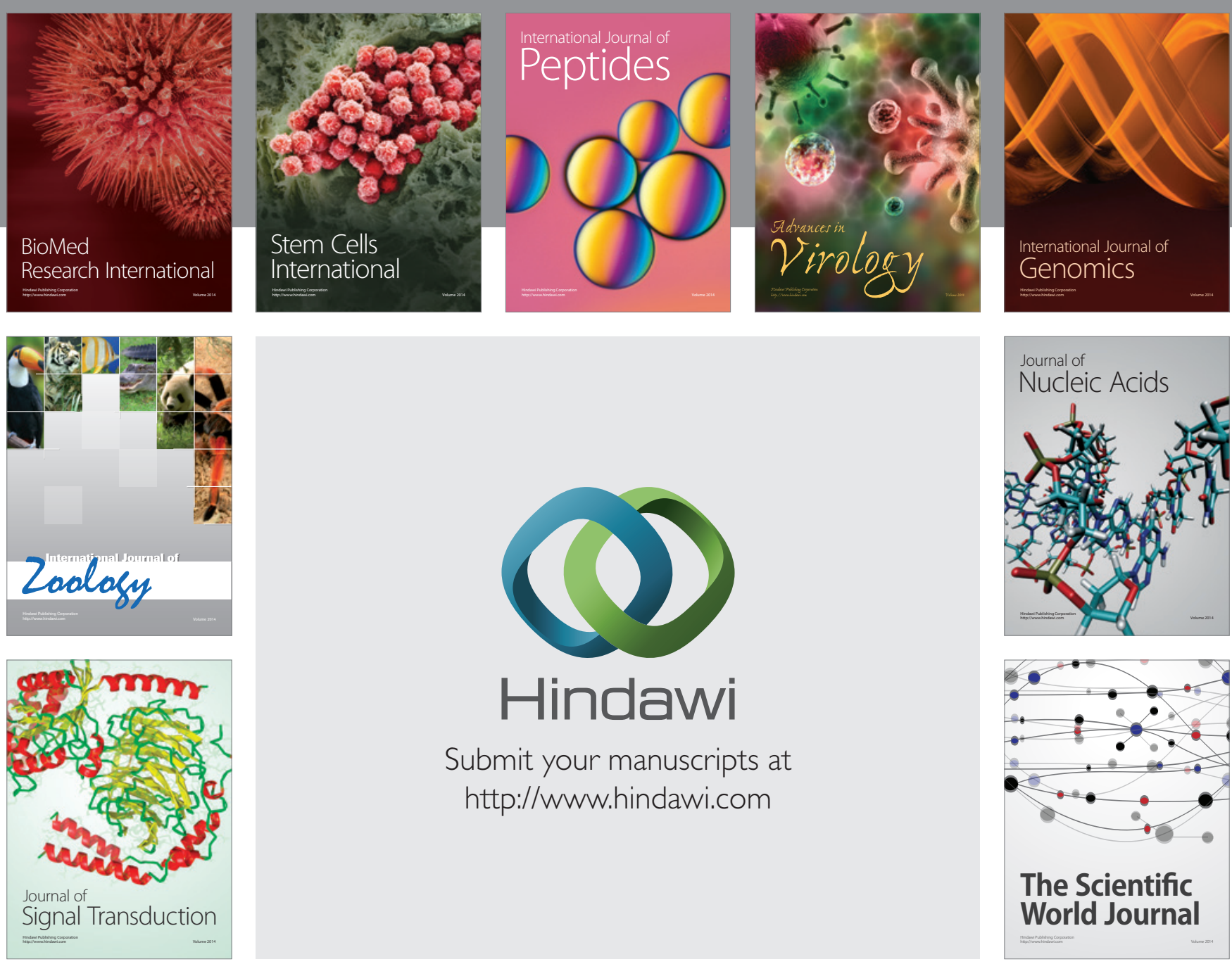

Submit your manuscripts at

http://www.hindawi.com
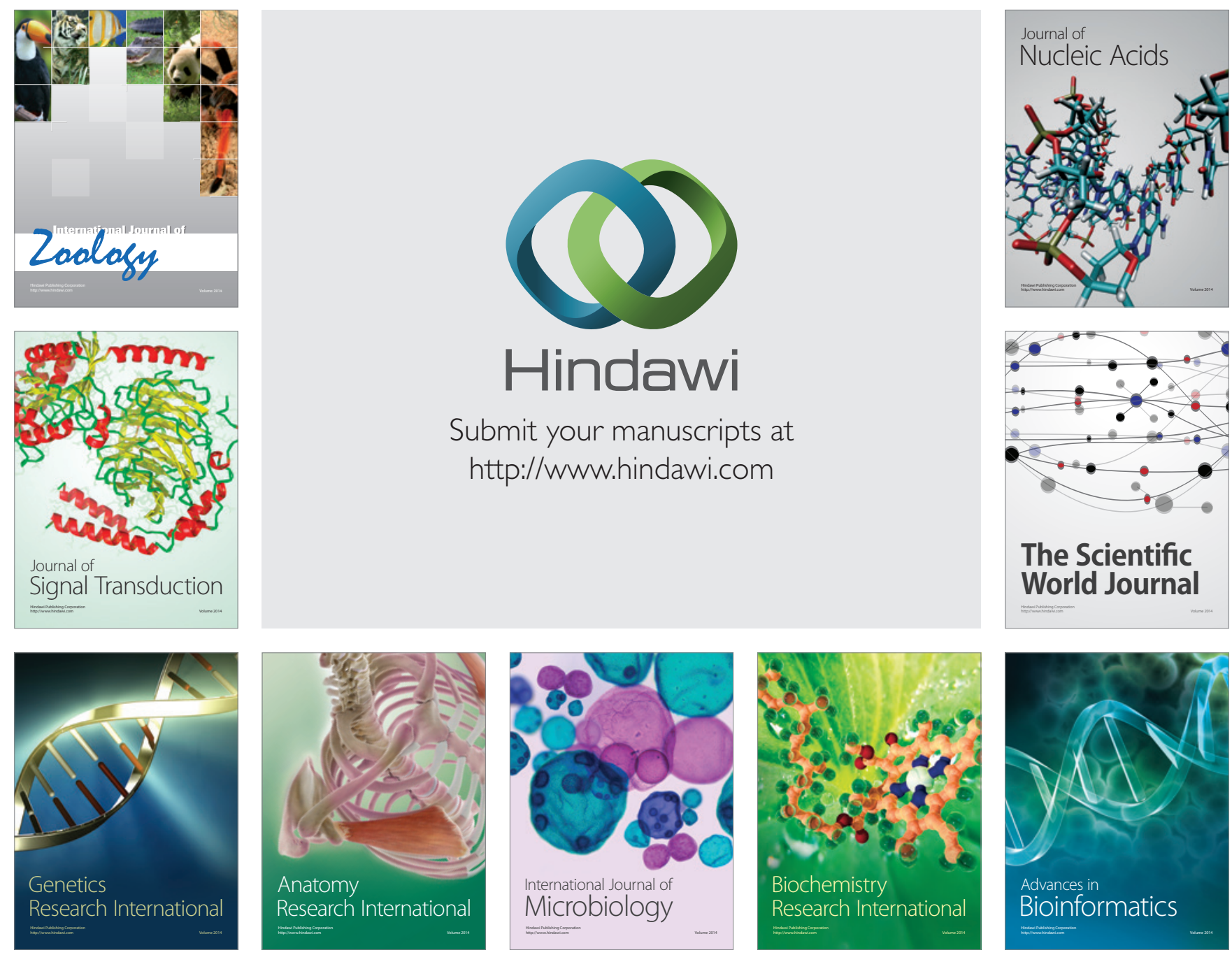

The Scientific World Journal
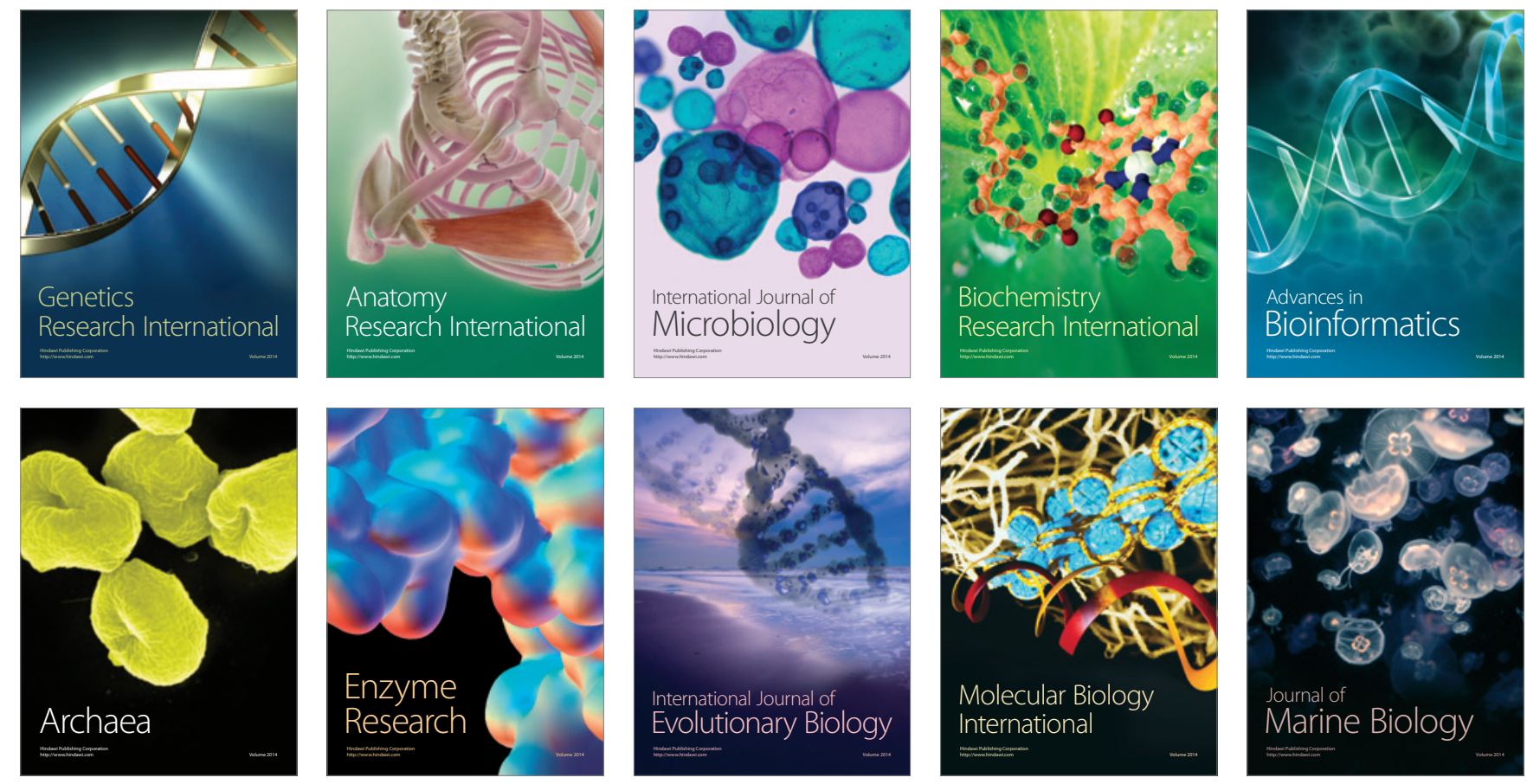